\title{
ANALISIS FRAMING PEMBERITAAN MEDIA ONLINE MENGENAI KASUS PEDOFILIA DI AKUN FACEBOOK
}

\author{
Rieka Mustika \\ Puslitbang Aptika IKP Kementerian Komunikasi dan Informatika \\ Jl. Medan Merdeka Barat No. 9, Jakarta Pusat, DKI Jakarta, 10110, Indonesia \\ No. HP: 08567360380 \\ E-mail: riek001@kominfo.go.id
}

Naskah diterima tanggal 22 Juni 2017, direvisi tanggal 28 Agustus 2017, disetujui tanggal 11 September 2017

\section{FRAMING ANALYSIS OF ONLINE MEDIA IN DISCLOSURE OF PEDOPHILIA ON FACEBOOK ACCOUNT CASE}

\begin{abstract}
The emergence of many cases against children that occurred to many people realize that children tend to be vulnerable victims of crime immoral. Sexual violence against children has a severe impact or effect on the child as a victim. In social media there is a Facebook group (FB) named Loli Candy's that collects pornographic photos of children. When the pedophile network on Facebook is revealed, every media has their own style in writing the news. Each media actually has a different ideology given that the media is not a free channel, but has constructed the news in such a way. Aim of this study is to be able to see how the two online media Kompas.com and Republika Online is framing about pedophilia case in a Facebook account. The framing analysis model used is Robert N. Entman. The difference in framing in the news raised by Kompas.com and Republika Online is most often seen is located in the selection of sources. Republika Online as a media nuances of Islam always chooses the speakers who have Islamic thought.
\end{abstract}

Keywords: framing, pedophilia, online media.

\begin{abstract}
Abstrak. Kasus terhadap anak yang sering terjadi membuat banyak pihak sadar betapa rentannya anak menjadi korban kejahatan asusila. Kekerasan seksual terhadap anak akan memberikan dampak atau efek yang berat kepada anak sebagai korban. Di media sosial terdapat grup Facebook (FB) bernama Loli Candy's yang mengumpulkan foto porno anak-anak. Pada kasus terungkapnya jaringan pedofilia di Facebook, beberapa media memiliki gaya masing-masing dalam penulisan beritanya. Setiap media sesungguhnya memiliki ideologi yang berbeda mengingat bahwa media bukanlah saluran yang bebas tetapi telah mengonstruksi berita sedemikian rupa. Tujuan penelitian ini adalah untuk melihat bagaimana dua media online yaitu Kompas.com dan Republika Online membingkai pemberitaan tentang pedofilia melalui akun Facebook. Model analisis framing yang digunakan adalah model Robert N. Entman. Perbedaan pembingkaian dalam berita yang dimunculkan oleh Kompas.com dan Republika Online yang paling sering terlihat adalah terletak pada pemilihan narasumber. Republika Online sebagai media bernuansa Islam selalu memilih narasumber yang memiliki pemikiran Islam.
\end{abstract}

Kata kunci: framing, pedofilia, media online.

\section{PENDAHULUAN}

Pornografi anak bukanlah kasus yang baru di Indonesia berdasarkan pemantauan Institute for Criminal Justice Reform (ICJR) pada bulan September 2016 hingga Februari
2017 tercatat enam kasus yang terungkap dengan jumlah korban mencapai 157 anak (Setiawan, 2017).

Kasus pelecehan seksual pedofilia yang cukup menggemparkan Indonesia di tahun 2014 yang lalu yaitu kasus yang menimpa 
korban murid Jakarta International School.(JIS) Masyarakat secara dekat mengikuti perkembangan kasus ini melalui berbagai media. Namun tidak hanya di Jakarta, kasus serupa juga menimpa 11 pelajar di Medan, yang dilakukan oleh gurunya dengan kewarganegaraan Singapura. Juga di Tenggarong, Kalimantan Timur, seorang guru melakukan sodomi kepada muridnya. Bahkan di tahun 2010 lalu, kasus pedofilia yang disertai kasus pembunuhan dan mutilasi menimpa 14 Baikuni yang dikenal dengan sebutan 'Babe' (VOA Indonesia, 2017).

Banyak kasus pedofilia di Indonesia menunjukkan anak-anak rentan menjadi korban. Lemahnya kendali sosial masyarakat menjadi salah satu penyebab maraknya kasus pedofilia. Fenomena pedofilia yang mayoritas terjadi di kota-kota besar seolah menjadi konsekuensi kehidupan masyarakat urban. Ritme kehidupan yang serba cepat dan cara berpikir rasional menciptakan individualisme di mana jalinan interaksi yang terjadi dengan lingkungan masyarakat lebih didasarkan faktor kepentingan daripada faktor kebutuhan untuk bersosialisasi.

Masyarakat urban seolah terisolasi dari lingkungan sekitar karena tidak sedikit dari mereka yang kadang tidak mengenali siapa tetangganya. Selain itu penyebab maraknya kasus pedofilia di Indonesia adalah faktor kemiskinan yang kini semakin buruk, membuat anak-anak kian rentan terhadap beberapa bentuk kejahatan dan eksploitasi. Lemahnya perangkat keamanan di Indonesia dalam membendung aksi para pedofilia yang kian canggih, juga turut mendukung maraknya kaum pedofilia menggunakan fasilitas internet untuk mencari mangsanya.

Pada kasus terungkapnya jaringan pedofilia di Facebook, bermula dari laporan Michelle Dian Lestari dan teman-temannya. Diawali dari laporan rekan Risrona Talenta Simorangkir di grup Fun-Fun Centilisius bahwa ada grup FB bernama Loli Candy's yang mengumpulkan foto porno anak-anak. Michelle dan Risrona mengaku sempat berkonsultasi ke seorang pegiat Lembaga Swadaya Masyarakat (LSM) untuk melaporkan ini, namun pegiat tersebut sekedar menyarankan untuk melaporkan ke Facebook agar akun Official Loli Candy's 18+ tersebut ditutup. Grup tersebut sempat ditutup setelah tautan dan screenshot-nya dikirim ke aduan konten Kementerian Komunikasi dan Informatika. Namun lantaran muncul lagi yang baru, akhirnya Michelle pun memutuskan untuk menghubungi Kepolisian. Ternyata Direktur Reserse Kriminal Khusus Polda Metro Jaya, Wahyu Hadiningrat, menindaklanjuti dengan cepat. Melalui WhatsApp, Michelle melemparkan tautan dan screenshot tersebut tanggal 6 Maret 2017 kepada Wahyu. Tiga hari setelahnya, yakni tanggal 9 Maret, empat administratornya dibekuk. Apa yang dilakukan Michelle bisa menjadi contoh kekuatan masyarakat menggunakan media sosial untuk mengungkap kejahatan berbasis internet (Nailufar, 2017).

Kenneth V. Lanning (2010) dalam Child Molesters: A Behavioral Analysis For Professionals Investigating the Sexual Exploitation of Children, mengatakan secara teknis istilah pedofil pada awalnya adalah istilah psikiatrik yang eksklusif dan hanya bisa ditegakkan berdasarkan diagnosis tertentu dari psikolog maupun psikiater yang ahli dalam bidangnya. Identik dengan istilah "paranoid" yang bisa dilekatkan pada seseorang tanpa terlebih dahulu melakukan diagnosis klinis, kini istilah pedofil telah semakin banyak digunakan orang termasuk pekerja sosial, jaksa, penegak hukum, dan reporter media untuk merujuk orang yang melakukan kekerasan seksual kepada anak sebagai pedofil.

Media massa berkontribusi terhadap perkembangan isu-isu terkait sekaligus memberikan pengaruh terhadap pembentukan opini publik. Dapat dikatakan, bahwa media tidak sekedar menjadi pihak yang pasif dan netral, tapi media memilih hal tertentu untuk ditonjolkan, dan meminimalkan hal yang lain. Dua sisi yang dikedepankan media dalam memberitakan kasus pedofilia dapat menimbulkan interpretasi-interpretasi yang beragam bagi khalayak yang mengonsumsinya.

Media online adalah media massa yang tersaji secara online di situs web (website) internet. Media online ini juga produk jurnalistik online. Jurnalistik online disebut 
juga cyber journalism didefinisikan sebagai "pelaporan fakta atau peristiwa yang diproduksi dan didistribusikan melalui internet".

Dengan munculnya media online ini informasi dari sebuah peristiwa akan sangat cepat dapat disampaikan oleh pemilik media kepada masyarakat melalui pemberitaan di media online (Romli \& Syamsul, 2012).

Kompas.com merupakan portal berita dalam grup Kompas Gramedia yang menyajikan berita dan peristiwa terkini di Indonesia. Sejak dirintis tahun 1995, pada awalnya Kompas.com dikenal dengan nama Kompas Online, sebuah situs yang berisi versi online dari harian Kompas. Seiring dengan makin meluasnya penggunaan internet di Indonesia, Kompas Online kemudian berkembang di bawah naungan PT Kompas Cyber Media (KCM). Sebagai unit bisnis baru, Kompas.com memiliki tim redaksi sendiri yang memproduksi konten berita yang berbeda, menyesuaikan dengan karakter pembaca online. Di tahun 2008, KCM bersinergi dengan grup-grup media di Kompas Gramedia untuk menjadikan Kompas.com sebagai megaportal berita dalam berbagai format multimedia (teks dan video) dan juga platform digital (desktop dan mobile site dari berbagai sistem operasi mobile) (Kompas, 2017a).

Selanjutnya Republika Online (ROL) hadir sejak 17 Agustus 1995, dua tahun setelah Harian Republika terbit. ROL merupakan portal berita yang menyajikan informasi secara teks, audio, dan video, yang terbentuk berdasakan teknologi hipermedia dan hiperteks. Dengan kemajuan informasi dan perkembangan sosial media, ROL kini hadir dengan berbagai fitur baru yang merupakan percampuran komunikasi media digital.

Setiap media memiliki gaya masingmasing dalam penulisan beritanya, mengingat bahwa media bukanlah saluran yang bebas tetapi telah mengonstruksi berita sedemikian rupa. Sebuah peristiwa yang sama dapat diperlakukan secara berbeda oleh media. Ada peristiwa yang diberitakan, ada yang tidak diberitakan, ada aspek yang ditonjolkan, ada aspek yang dihilangkan. Semua ini mengarah ke sebuah konsep yang disebut framing.
Framing adalah salah satu cara bagaimana peristiwa disajikan media dengan menekankan bagian tertentu, menonjolkan aspek tertentu, dan membesarkan cara bercerita tertentu dari suatu realitas atau peristiwa sehingga mudah diingat oleh khalayak (Eriyanto, 2002).

Media Republika dan Kompas online sesungguhnya memiliki ideologi yang berbeda. Republika memiliki garis yang berbeda dengan Kompas dan media umum normal lainnya. Kompas sejak awal hadirnya adalah garda NKRI dengan nasionalishumanis sebagai pilar. Sedangkan Republika memiliki ideologi perjuangan jihad-politis dalam tataran perjuangan ideologi Islam.

Untuk dapat melihat bagaimana kedua media online diatas membingkai pemberitaan tentang pedofilia melalui akun Facebook digunakan model analisis framing model Robert N. Entman dengan menekankan pada penonjolan kerangka pemikiran, perspektif dan konsep tentang memaknai suatu berita.

Perumusan masalah dalam penelitian ini adalah bagaimana Kompas.com dan Republika online membingkai (frame) pemberitaan tentang pedofilia di media sosial. Adapun tujuan penelitian ini adalah untuk mendapat gambaran dan menganalisis pemahaman cara Kompas.com dan Republika Online dalam membingkai (frame) pemberitaan tentang pedofilia melalui akun Facebook.

\section{LANDASAN KONSEP}

Indonesia memang menjadi salah satu negara yang rawan kasus pedofilia. Tidak sedikit pula pelaku berasal dari luar negeri. Berdasarkan penelitian dalam jurnal Trend and Issue in Crime \& Criminal Justice (Ogloff, Cutajar, Mann, et al., 2011), mereka yang menjadi korban kekerasan seksual, 33 persen hingga 75 persen akan menjadi pelaku di masa mendatang.

Pedofilia juga dipengaruhi oleh faktor frekuensi kebersamaan dengan anak, pekerjaan, pengalaman, dan pengetahuan (Vandra, 2015). Perbedaan penelitian yang telah dilakukan sebelumnya oleh Vandra (2015) dengan penelitian ini adalah penelitian 
tersebut memfokuskan bagaimana pemaknaan kasus pedofilia oleh khalayak. Sedangkan dalam penelitian ini lebih terfokus pada pembingkaian berita mengenai pedofilia yang terjadi di media sosial Facebook.

Penelitian tentang pembingkaian berita di media online juga telah banyak dilakukan, salah satunya penelitian yang dilakukan oleh Gema Mawardi (2012) dengan judul penelitian Pembingkaian Berita Media Online (Analisis Framing Berita Mundurnya Surya Paloh dari Partai Golkar di mediaindonesia.com dan vivanews.com tanggal 7 September 2011). Jika dilihat dari teknik analisis datanya, penelitian ini juga menggunakan analisis framing, namun perbedaan dengan penelitian sebelumnya yang menggunakan model analisis Pan dan Kosicki, penelitian ini menggunakan metode analisis framing model Robert N. Entman dengan empat perangkat yaitu Define Problems, Diagnose Cause, Make Moral Judgement, dan Treatment Recommendation dengan menekankan pada penonjolan kerangka pemikiran, perspektif, dan konsep tentang memaknai suatu berita.

\section{Media Berita Online}

Kridalaksana dalam Sumadiria (2005) mengategorikan media online sebagai jurnalistik media massa. Secara lebih khusus Kridalaksana mengategorikan media online bersama televisi sebagai media elektronik audio visual yang berarti dapat dinikmati dengan melihat maupun mendengar. Media online sendiri, sering disebut juga sebagai $\mathrm{New}$ Media. New media adalah bentuk-bentuk media dan isi media yang diciptakan dan dibentuk oleh perubahan teknologi. Internet adalah salah satu new media di abad 21 . Sebagai teknologi baru, bentuk media dan teknologi muncul secara bersamaan, dan disebut media convergence. Media convergence adalah definisi umum dari kombinasi antara dua atau lebih media tradisional yang menjadi satu proses serta memberikan dampak bagi media lain dan penggunanya.

Perkembangan media massa membuat orang bisa menikmati berita dari mana saja, termasuk dengan adanya media online. Dalam buku Online Journalism: Principles and
Practices of News for The Web (Foust, 2005), ada beberapa keuntungan yang bisa diperoleh dari jurnalisme online dan salah satunya adalah immediacy. Immediacy ini memungkinkan informasi untuk disampaikan secara cepat dan langsung kepada audiens sehingga tidak perlu menunggu penerbitan seperti yang dilakukan oleh surat kabar.

\section{Konstruksi Realitas Media}

Berita merupakan informasi yang layak disajikan kepada publik, seperti informasi yang bersifat faktual, aktual, objektif, penting dan menarik perhatian publik (Suryawati, 2011). Sebuah berita yang disajikan kepada publik harus memiliki nilai berita yaitu acuan yang digunakan jurnalis yakni reporter dan editor untuk memutuskan fakta yang pantas dijadikan berita dan memilih mana yang lebih baik.

Media massa merupakan agen sosialisasi sekunder yang dampak penyebarannya paling luas dibanding agen sosialisasi lain. Meskipun dampak yang diberikan media massa tidak secara langsung terjadi, namun cukup signifikan dalam memengaruhi seseorang, baik dari segi kognisi, afeksi, maupun konatifnya (Gerbner, 2007).

Di samping kepentingan ideologi antara masyarakat dan negara, dalam suatu institusi media massa juga memiliki kepentingan tersendiri seperti kepentingan pemilik modal, kepentingan keberlangsungan (sustainability) lapangan kerja bagi para karyawan dan sebagainya. Kondisi ini membuat berita bukan lagi berada sebagai pihak yang netral, namun akan bergerak sesuai dengan kepentingan yang bermain di dalamnya. Sehingga hal inilah yang membuat bias berita di media massa menjadi sesuatu yang sulit dihindari (Sobur, 2001).

Teori tentang proses konstruksi realitas sosial yang digunakan oleh Peter L. Berger dan Thomas Luckmann melalui bukunya yang berjudul, "The Social Construction of Reality: A Treatise in The Sociological of Knowledge" tahun 1966 makin tersebar luas. Menurut mereka, realitas sosial dikonstruksi melalui proses eksternalisasi, objektivasi, dan internalisasi. Konstruksi sosial tidak berlangsung dalam ruangan hampa, namun 
sarat dengan kepentingan-kepentingan (Bungin, 2008).

Pertama, eksternalisasi, yaitu usaha pencurahan atau ekspresi diri manusia ke dalam dunia, baik dalam kegiatan mental maupun fisik. Ini adalah sifat dasar manusia. Kedua, objektivasi, yaitu hasil yang telah dicapai, baik mental maupun fisik dari kegiatan eksternalisasi manusia tersebut. Hasil itu menghasilkan realitas objektif yang bisa jadi akan menghadapi si penghasil itu sendiri sebagai suatu fakta yang berada di luar dan berlainan dari manusia yang menghasilkannya. Ketiga, internalisasi, proses internalisasi lebih merupakan penyerapan kembali dunia objektif ke dalam kesadaran sedemikian rupa sehingga subjek individu dipengaruhi oleh struktur dunia sosial (Bungin, 2008). Oleh karena itu bagi kaum konstruktivis, realitas berita hadir dalam keadaan subjektif.

\section{Teori Framing Model Robert N Entman}

Entman melihat framing dalam dua dimensi besar: seleksi isu dan penekanan atau penonjolan aspek-aspek tertentu dari realitas/isu. Penonjolan adalah proses membuat informasi menjadi lebih bermakna, lebih menarik, berarti, atau lebih diingat oleh khalayak (Eriyanto, 2002). Dalam praktiknya, framing dijalankan oleh media dengan menyeleksi isu tertentu dan mengabaikan isu yang lain, dan menonjolkan aspek dari isu tersebut dengan menggunakan berbagai strategi wacana-penempatan yang menyolok (menempatkan di-headline depan atau di bagian belakang), pengulangan, pemakaian grafis untuk mendukung dan memperkuat penonjolan, pemakaian label tertentu ketika menggambarkan orang/peristiwa yang diberitakan, asosiasi terhadap simbol budaya, generalisasi, simplifikasi, dan lain-lain. Semua aspek itu dipakai untuk membuat dimensi tertentu dari konstruksi berita menjadi bermakna dan diingat oleh khalayak.

Frame berita timbul dalam dua level. Pertama, konsepsi mental yang digunakan untuk memproses informasi dan sebagai karakteristik dari teks berita. Kedua, perangkat spesifik dari narasi berita yang dipakai untuk membangun pengertian mengenai peristiwa.
Frame berita dibentuk dari kata kunci, metafora, konsep, simbol, citra yang ada dalam narasi berita. Karenanya, frame dapat dideteksi dan diselidiki dari kata, citra, dan gambar tertentu yang memberi makna tertentu dari teks baru. Kosa kata dan gambar itu ditekankan dalam teks sehingga lebih menonjol dibandingkan bagian lain dalam teks. Itu dilakukan lewat pengulangan, penempatan yang lebih menonjol atau menghubungkan dengan bagian lain dalam teks berita, sehingga bagian itu lebih menonjol, lebih mudah diingat, dilihat, dan lebih memengaruhi khalayak. Secara luas pendefinisian masalah ini menyertakan, di dalamnya, konsepsi dan skema interpretasi wartawan.

\section{Pedofilia Grup Facebook Loli Candy's}

Pedofilia, berasal dari bahasa Yunani yaitu paidos yang berarti anak-anak dan philia yang berarti cinta. Pedofilia adalah kelainan psikoseksual, di mana orang dewasa atau remaja memiliki preferensi seksual terhadap anak-anak praremaja. Gangguan ini juga dianggap sebagai parafilia, adalah sekelompok gangguan yang didefinisikan sebagai aktivitas seksual yang abnormal (Kompas, 2017c).

Secara umum pedofilia didefinisikan sebagai seseorang yang mendapatkan kepuasan seksual melalui kontak dengan anak di bawah umur. Perilaku pedofilia tidak selalu identik dengan adanya kontak seksual dengan anak-anak, karena bisa juga terjadi melalui imajinasi/fantasi seksual maupun lewat penggunaan internet. Menurut Diagnostik dan Statistik Manual Gangguan Jiwa (DSM), pedofilia adalah parafilia di mana seseorang memiliki hubungan yang kuat dan berulang terhadap dorongan seksual dan fantasi tentang anak prapuber dan di mana perasaan mereka memiliki salah satu peran atau yang menyebabkan penderitaan atau kesulitan interpersonal (American Psyciatric Association, 2013).

Pelaku pedofilia biasanya mencari korbannya dari teman-teman keluarga atau kerabat mereka. Jenis kegiatan pedofilia ini sendiri sangat bervariasi, mulai dari hanya melihat bentuk tubuh korbannya, menyentuh 
hingga melibatkan seks oral atau menyentuh alat kelamin anak atau pelaku.

Grup Facebook Loli candy's yang notabene merupakan kumpulan dari para pelaku pedofilia ini lahir dari forum percakapan WhatsApp bernama "Indonesia Candy's" pada akhir September 2016. Grup WhatsApp memang hanya bisa menampung 256 anggota, sedangkan grup Facebook anggotanya tidak terbatas. Namun Facebook juga sebenarnya aktif memblokir grup-grup penyebar konten pornografi. Untuk mengakali pemblokiran, admin grup tidak langsung mengunggah gambar utuh. Ketika ada yang mengirim gambar vulgar, admin grup lebih dulu menyensornya dengan menutupi bagian organ vital.

Namun mereka akan memasukkan tautan untuk menuju situs asli yang menyediakan gambar tersebut. Tautan situs pun tak dimasukkan mentah-mentah ke Facebook, namun tautan itu dibelokkan dulu ke situs ShtMe.co. Dengan memutar tautan ke ShtMe.co lebih dulu, pengunggah tautan juga mendapat keuntungan tambahan berupa bayaran untuk setiap klik (clickpay). Pengunggah mendapat Rp12-20 dari setiap orang yang mengklik tautan tersebut. Uang virtual itu selanjutnya akan terakumulasi di akun si pengunggah yang terdaftar di ShtMe.com. Uang itu bisa dicairkan dalam bentuk pulsa telepon.

Ada beberapa syarat untuk masuk ke grup. Antara lain calon anggota harus mengirim beberapa konten porno anak ke nomor WhatsApp admin yang tertera di laman grup. Setelah masuk, anggota grup wajib aktif mengirimkan gambar atau video. Jika anggota pasif, admin akan mengeluarkannya dari grup. Konten yang diunggah anggota Loli candy's ini tak melulu foto atau video vulgar. Anggota kelompok ini juga mengunggah gambar anakanak di sekitar mereka. Beberapa gambar anak kecil diambil di tempat umum seperti objek wisata dan pusat belanja. Adapula foto yang diambil dari akun media sosial lain. Sedikitnya para pelaku ini bergabung dengan 11 grup WhatsApp mancanegara. Domainnya antara lain terdeteksi berada di Peru, Argentina, Kolombia, dan Elsalvador, rata-rata grup tersebut beranggotakan 100-200 anggota (Tempo, 2017).

\section{METODE PENELITIAN}

Penelitian ini menggunakan pendekatan kualitatif. Pendekatan kualitatif merupakan prosedur penelitian yang menghasilkan data deskriptif berupa kata-kata tertulis atau lisan dari orang-orang atau perilaku yang dapat diamati. Pendekatan kualitatif dalam penelitian ini digunakan untuk mendapatkan gambaran utuh dalam memaknai suatu realitas yang diteliti dengan pendekatan menyeluruh, dan tidak melakukan pengukuran pada bagianbagian realitas. Sifat penelitian ini berdasarkan tujuannya adalah penelitian deskriptif karena diharapkan dapat memberikan pemahaman yang lebih komprehensif terhadap topik ini. Penelitian deskriptif menyediakan gambaran tentang konteks, situasi, dan kejadian, fenomena dari apa yang diamati.

Pada penelitian ini pengambilan data diperoleh dengan mengunduh berita mengenai pedofilia melalui akun Facebook yang dimuat dalam portal berita Republika.co.id (Republika, 2017) dan Kompas.com (Kompas, 2017b) selama periode bulan Maret sampai dengan April 2017. Dalam penelitian ini data akan disajikan dalam bentuk tabel hasil analisis dengan menggunakan model Robert Entman.

Analisis framing model Entman melihat framing dalam dua dimensi besar yaitu seleksi isu dan penekanan atau penonjolan aspekaspek tertentu dari realitas/isu (Eriyanto, 2002). Penonjolan adalah proses membuat informasi menjadi lebih bermakna, lebih menarik, berarti, atau lebih diingat oleh khalayak. Dalam konsepsi Entman, framing pada dasarnya merujuk pada pemberian definisi, penjelasan, evaluasi, dan rekomendasi dalam suatu wacana untuk menekankan kerangka berpikir tertentu terhadap peristiwa yang diwacanakan. Model analisis Entman tersebut menggambarkan secara luas bagaimana peristiwa dimaknai dan ditandakan oleh wartawan. Elemen-elemen framing Entman terdiri dari empat hal yaitu:

1. Define problems (pendefinisian masalah); 
Merupakan elemen utama framing yang menekankan bagaimana peristiwa dipahami oleh wartawan. Peristiwa yang sama dapat dipahami secara berbeda pula. Bingkai yang berbeda akan menyebabkan realitas bentukan yang berbeda pula.

2. Diagnose causes (memperkirakan penyebab masalah);

Merupakan elemen framing untuk membingkai siapa aktor/penyebab dari suatu peristiwa. Penyebab di sini bisa apa (what) ataupun siapa (who).

3. Make moral judgement (membuat pilihan moral);

Merupakan elemen pemberi argumentasi atau pembenaran yang akan mendukung pendefinisian dan penyebab suatu masalah.

4. Treatment recommendation (menekankan penyelesaian).
Elemen ini merangkum solusi yang diinginkan wartawan dengan melihat siapa penyebab masalah dan seperti apa peristiwa itu ingin dilihat.

\section{HASIL PENELITIAN DAN PEMBAHASAN}

\begin{abstract}
Analisis Teks
Penelitian ini menggunakan berita dari dua media online yaitu Kompas.com, dan Republika Online terkait pedofilia. Berdasarkan tema kajian, yaitu pedofilia, maka berita dipilih berdasarkan ada atau tidaknya pembahasan terkait pedofilia.

Analisis akan dilakukan terhadap tiga tabel analisis framing di bawah ini, untuk memberikan kenyamanan dalam pembacaan, peneliti akan memaparkan hasil analis framing berdasarkan masing-masing media online.
\end{abstract}

Tabel 1

Analisis Framing 1

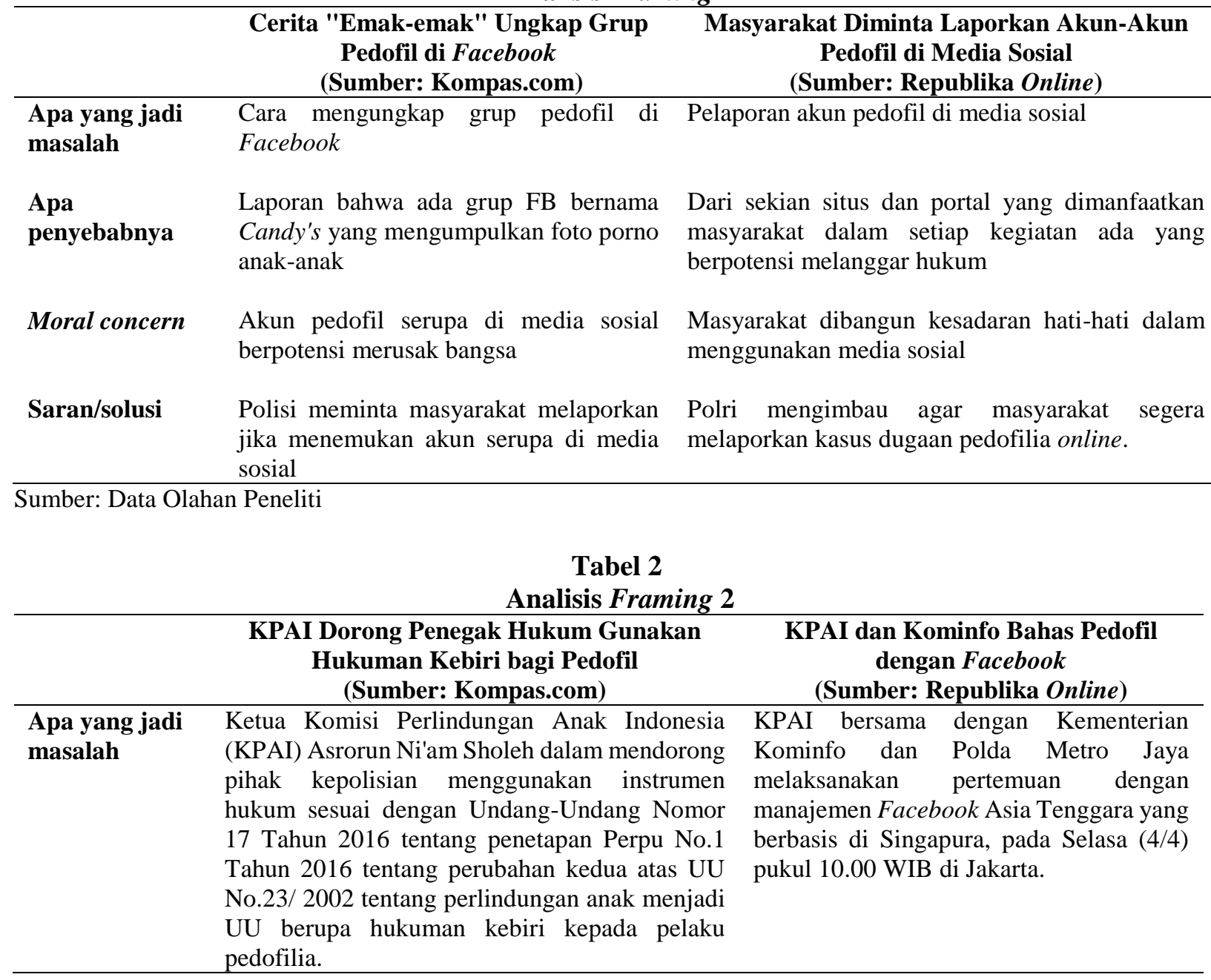




\begin{tabular}{|c|c|c|}
\hline $\begin{array}{l}\text { Apa } \\
\text { penyebabnya }\end{array}$ & $\begin{array}{l}\text { Kejahatan seksual yang dilakukan para pelaku } \\
\text { termasuk kejahatan luar biasa. Ia mengatakan } \\
\text { penerapan hukuman itu sejalan dengan } \\
\text { komitmen Presiden Joko Widodo saat } \\
\text { menerbitkan aturan tersebut guna melindungi } \\
\text { anak-anak Indonesia. }\end{array}$ & $\begin{array}{l}\text { Menindaklanjuti adanya beberapa kasus } \\
\text { kejahatan anak berbasis daring, khususnya } \\
\text { kasus pedofila anak melalui } \\
\text { grup Facebook Loli Candy yang sempat } \\
\text { meresahkan masyarakat. }\end{array}$ \\
\hline Moral concern & $\begin{array}{l}\text { Agar orang yang mau melakukan berpikir seribu } \\
\text { kali untuk melakukannya karena hukumannya } \\
\text { sangat berat. Makanya aparat penegak hukum } \\
\text { harus menggunakan instrumen yang tersedia } \\
\text { ini untuk kepentingan penjeraan. }\end{array}$ & $\begin{array}{l}\text { Pentingnya komitmen bersama dalam } \\
\text { perlindungan anak } \\
\text { media online, khususnya Facebook } \\
\text { dengan langkah-langkah proaktif untuk } \\
\text { pencegahan dan penindakan terhadap } \\
\text { tindak kejahatan terhadap anak } \\
\text { melalui Facebook. }\end{array}$ \\
\hline Saran/solusi & $\begin{array}{l}\text { Pelaksanaan hukuman sesuai UU } 17 \text { Tahun } 2016 \\
\text { tentang perubahan kedua tentang UU } 23 \text { tahun } \\
2002 \text { Perlindungan Anak dengan hukuman kebiri } \\
\text { hingga hukuman mati. }\end{array}$ & $\begin{array}{l}\text { FB menyediakan fasilitas pelaporan untuk } \\
\text { masyarakat jika menemukan konten yang } \\
\text { melanggar aturan. Untuk mempercepat } \\
\text { pemblokiran atas laporan konten yang } \\
\text { memiliki indikasi eksploitasi seksual anak, } \\
\text { KPAI dapat langsung berkoordinasi ke } \\
\text { divisi content and safety Facebook. } \\
\text { KPAI menyampaikan pentingnya } \\
\text { pengawasan dan pengawalan regulasi } \\
\text { yang dibuat secara internal oleh Facebook } \\
\text { dengan membentuk tim siber. internal } \\
\text { untuk mengontrol dan melakukan patroli } \\
\text { siber sehingga konten-konten negatif } \\
\text { dapat dicegah sedari awal. }\end{array}$ \\
\hline
\end{tabular}

Sumber: Data Olahan Peneliti

Tabel 3

Analisis Framing 3

\begin{tabular}{|c|c|c|}
\hline & $\begin{array}{c}\text { Pemprov DKI Dukung Upaya Polda } \\
\text { Membasmi Jaringan Pedofil di Facebook } \\
\text { (Sumber: Kompas.com) }\end{array}$ & $\begin{array}{c}\text { Pemuda Muhammadiyah: Usut Tuntas } \\
\text { Jaringan Pedofil Internasional } \\
\text { (Sumber: Republika Online) }\end{array}$ \\
\hline $\begin{array}{l}\text { Apa yang jadi } \\
\text { masalah }\end{array}$ & $\begin{array}{l}\text { Pemprov DKI mendukung Polda Metro Jaya } \\
\text { membongkar jaringan pedofil juga mendukung } \\
\text { pemberantasan prostitusi online yang lebih luas } \\
\text { lagi. }\end{array}$ & $\begin{array}{l}\text { Pimpinan Pusat Pemuda Muhammadiyah } \\
\text { mengapresiasi upaya Polda Metro Jaya } \\
\text { yang berhasil membongkar jaringan } \\
\text { pedofil internasional melalui media sosial, } \\
\text { Facebook grup. }\end{array}$ \\
\hline $\begin{array}{l}\text { Apa } \\
\text { penyebabnya }\end{array}$ & $\begin{array}{l}\text { Komunitas pedofil yang saling berbagi konten } \\
\text { pelecehan dan pencabulan terhadap anak-anak. }\end{array}$ & $\begin{array}{l}\text { Grup jaringan pedofil internasional yang } \\
\text { dibongkar polisi itu memiliki } 7.469 \\
\text { anggota. Belum diketahui jumlah anak } \\
\text { Indonesia yang menjadi korban para } \\
\text { pemangsa anak-anakitu. }\end{array}$ \\
\hline Moral concern & $\begin{array}{l}\text { Pemprov DKI bersedia membantu polisi jika } \\
\text { dibutuhkan. }\end{array}$ & $\begin{array}{l}\text { Ketua PP Pemuda Muhammadiyah, Jasra } \\
\text { Putra dalam pernyataan sikapnya, } \\
\text { mengutuk dan mengecam keras } \\
\text { kebiadaban pelaku predator anak yang } \\
\text { sudah merusak dan mencabik masa depan } \\
\text { anak-anak. }\end{array}$ \\
\hline
\end{tabular}




\begin{tabular}{|c|c|c|}
\hline Saran/solusi & $\begin{array}{l}\text { Pemprov DKI Jakarta bisa berkoordinasi dengan } \\
\text { Polda Metro Jaya untuk membongkar jaringan } \\
\text { ini. } \\
\text { Pemprov DKI bersedia membantu polisi dengan } \\
\text { memanfaatkan jaringan Diskominfo. }\end{array}$ & $\begin{array}{l}\text { Pemuda Muhammadiyah meminta kepada } \\
\text { penegak hukum untuk mengusut tuntas } \\
\text { jaringan online kejahatan seksual anak dan } \\
\text { melakukan penegakan hukum maksimal } \\
\text { terhadap pelaku dewasa. } \\
\text { Pemuda Muhammadiyah juga mendesak } \\
\text { pemerintah, kementerian, dan lembaga } \\
\text { terkait untuk melakukan langkah-langkah } \\
\text { nyata dalam penanganan anak korban } \\
\text { pedofil yang diduga jumlahnya mencapai } \\
\text { ribuan. mengimbau } \\
\text { Pemuda Muhammadiyah menara selalu } \\
\text { orang tua dan masyarakat untuk melindungi, } \\
\text { waspada dalam } \\
\text { mendampingi, dan memberikan } \\
\text { pendidikan bagi anak-anak dalam } \\
\text { mengakses internet. }\end{array}$ \\
\hline
\end{tabular}

Sumber: Data Olahan Peneliti

\section{Hasil Analisis Framing terhadap Kompas.com}

Framing pertama Kompas.com pada tanggal 27 Maret 2017 yang berjudul Cerita "Emak-emak" Ungkap Grup Pedofil di Facebook ini ditulis oleh Nibras Nada Nailufar (2017). Berita ini mengangkat kronologis awal mulanya pelaporan aduan konten ke Kementerian Komunikasi dan Informatika dan akhirnya diadukan ke Kepolisian. Terdapat grup Facebook bernama Loli Candy's yang mengumpulkan foto porno anak-anak. Hanya membutuhkan waktu tiga hari, polisi dapat membekuk empat administratornya.

Berita ini juga menekankan salah satu contoh kekuatan media sosial untuk mengungkap kejahatan berbasis internet.Wakil Direktur Reserse Kriminal Khusus Polda Metro Jaya AKBP Akhmad Yusep meminta masyarakat melaporkan jika menemukan akun serupa di media sosial Facebook atau lainnya.

Narasi yang disampaikan oleh Kompas.com menyatakan bahwa akun Official Loli Candy's 18+ sudah ditutup. Setidaknya telah ada 600 foto dan video bermuatan pornografi anak. Polisi tengah memburu anggota lainnya yang sempat mengunggah pornografi anak, apalagi benar terbukti pernah melakukan pencabulan. Untuk mengungkapnya, polisi tengah mengolah data dari Facebook terkait riwayat anggota-nya.

Akun Official Candy's Groups yang juga dikelola oleh mereka, memang masih ada namun berangsur-angsur ditinggalkan anggotanya setelah polisi mengungkap kasus ini ke publik. Para pelaku disebut masih terhubung dengan banyak akun lainnya. Akun Facebook sebelumnya ada 12 akun, di antaranya ada satu akun adalah lokal Indonesia, 11 akun lainnya itu masih diupayakan koordinasinya dalam penanganannya karena bersifat internasional.

Kompas.com menilai akun pedofil serupa di media sosial itu berpotensi merusak bangsa. Sebagai solusi penyelesaian masalah pedofil di media sosial, polisi meminta masyarakat melaporkan jika menemukan akun serupa di media sosial sehingga masalah bisa diselesaikan dengan tuntas.

Framing kedua Kompas.com pada tanggal 21 Maret 2017, yang berjudul KPAI Dorong Penegak Hukum Gunakan Hukuman Kebiri bagi Pedofil ditulis oleh David Oliver Purba. Berita ini menyoroti pernyataan dari Ketua Komisi Perlindungan Anak Indonesia (KPAI) Asrorun Ni'am Sholeh dalam mendorong pihak kepolisian menggunakan instrumen hukum sesuai dengan UndangUndang Nomor 17 Tahun 2016 tentang berupa hukuman kebiri kepada pelaku pedofilia. Menurutnya kejahatan seksual yang dilakukan para pelaku termasuk kejahatan luar biasa. Ia mengatakan penerapan hukuman itu sejalan dengan komitmen Presiden Joko Widodo saat menerbitkan aturan tersebut guna melindungi anak-anak Indonesia.

Berdasarkan penyebab di atas, agar orang yang mau melakukan berpikir seribu 
kali untuk melakukan kejahatan pedofil terhadap anak yang pastinya akan mendapat hukuman yang sangat berat, oleh karenanya aparat penegak hukum harus menggunakan instrumen yang tersedia ini untuk kepentingan penjeraan.

Solusi pelaksanaan hukuman sesuai Undang-undang (UU) Nomor 17 Tahun 2016 Tentang Perubahan Kedua Undang-undang Nomor 23 Tahun 2002 Tentang Perlindungan Anak adalah dengan hukuman kebiri hingga hukuman mati. Soal bahwa hukuman itu bersifat kontroversial atau tidak, Asrorun mengatakan bahwa hal itu sudah selesai dibahas sebelum aturan tersebut diberlakukan.

Framing ketiga Kompas.com pada tanggal 17 Maret 2017, yang berjudul Pemprov DKI Dukung Upaya Polda Membasmi Jaringan Pedofil di Facebook ditulis oleh Jessi Carina.

Berita ini membahas mengenai Pemerintah Provinsi (Pemprov) DKI yang mendukung Polda Metro Jaya untuk membongkar jaringan pedofil juga mendukung pemberantasan prostitusi online yang lebih luas lagi.

Grup Facebook "Official Candy's Groups" adalah komunitas pedofil yang saling berbagi konten pelecehan dan pencabulan terhadap anak-anak. Polisi telah mengamankan empat orang administrator grup tersebut.

Kompas.com melansir bahwa tindak kekerasan seksual terhadap anak oleh komunitas pedofil yang tergabung dalam grup Facebook "Official Candy's Groups" sudah saling berbagi konten pelecehan dan pencabulan terhadap anak-anak. Solusi yang dapat dilakukan Pemprov DKI adalah Pemprov DKI bersedia membantu polisi jika dibutuhkan. Pemprov DKI Jakarta bisa berkoordinasi dengan Polda Metro Jaya untuk membongkar jaringan ini. Selain itu juga Pemprov DKI bersedia membantu polisi dengan memanfaatkan jaringan Dinas Komunikasi dan Informatika (Diskominfo).

\section{Hasil Analisis Framing terhadap Republika Online}

Framing pertama Republika Online pada tanggal 21 Maret 2017 yang berjudul
Masyarakat Diminta Laporkan Akun-Akun Pedofil di Media Sosial, diliput oleh Mabruroh dan ditulis oleh Bayu Hermawan. Dalam berita disebutkan bahwa Polri mengimbau agar masyarakat segera melaporkan kasus dugaan pedofilia online.

Tujuannya agar kasus-kasus penyimpangan seksual kepada anak-anak kecil itu tidak terulang lagi. Selain itu juga ingin membangun kesadaran dan kehati-hatian masyarakat dalam menggunakan media sosial, alasannya karena dari sekian situs dan portal itu ada saja yang berpotensi melanggar hukum.

Penekanan dalam berita ini lebih kepada sanksi yang akan dikenakan pada akun yang dibentuk pada September 2016 lalu dan sudah ada 7.427 anggota di dalamnya terkait undangundang.

Kepada para tersangka dikenakan ancaman hukuman Pasal 27 ayat (1) Jo Pasal 45 ayat (1) UU No. 19 Tahun 2016 Tentang Perubahan Atas UU No. 11 Tahun 2008 Tentang Informasi dan Transaksi Elektronik dan/atau Pasal 4 ayat Jo Pasal 29 dan/atau Pasal 4 ayat (2) Jo Pasal 30 UU No. 44 Tahun 2008 Tentang Pornografi. Pasal 27 ayat (1) Jo Pasal 45 ayat(1) UU No. 19 Tahun 2016 Tentang Perubahan Atas UU RI No. 11 Tahun 2008, dipidana dengan pidana penjara paling lama enam tahun dan/atau denda paling banyak satu miliar rupiah. Pasal 4 ayat (1) Jo Pasal 29 UU No. 44 Tahun 2008, dipidana dengan pidana penjara paling singkat enam bulan dan paling lama 12 tahun dan/atau pidana denda paling sedikit Rp250.000.000 dan paling banyak Rp6.000.000.000.Pasal 4 ayat (2) Jo Pasal 30 UU No. 44 Tahun 2008, dipidana dengan pidana penjara paling singkat enam bulan dan paling lama enam tahun dan/atau pidana denda paling sedikit Rp250.000.000 dan paling banyak Rp3.000.000.000

Republika melansir bahwa dari sekian situs dan portal yang dimanfaatkan masyarakat dalam setiap kegiatan ada yang berpotensi melanggar hukum, untuk itu masyarakat perlu dibangun kesadaran untuk berhati-hati dalam menggunakan media sosial. Sebagai solusi Polri mengimbau agar masyarakat segera melaporkan kasus dugaan pedofilia online. 
Framing kedua Republika Online pada tanggal 4 April 2017 yang berjudul KPAI dan Kominfo Bahas Pedofil dengan Facebook diliput oleh Kabul Astuti dan ditulis oleh Ani Nursalikah.

Berita ini menjelaskan bahwa KPAI bersama dengan Kementerian Kominfo dan Kepolisian Daerah (Polda) Metro Jaya melaksanakan pertemuan dengan manajemen Facebook Asia Tenggara yang berbasis di Singapura, pada Selasa (4/4) pukul 10.00 WIB di Jakarta. Pertemuan pembahasan ini dilakukan menindaklanjuti adanya beberapa kasus kejahatan anak berbasis dalam jaringan (daring), khususnya kasus pedofila anak melalui grup Facebook Loli Candy yang sempat meresahkan masyarakat.

Republika.co.id menilai bahwa pentingnya komitmen bersama dalam perlindungan anak di media online, khususnya Facebook, dengan langkah-langkah proaktif untuk pencegahan dan penindakan terhadap tindak kejahatan terhadap anak melalui Facebook.

Sebagai tindak lanjut dari pihak Facebook, mereka menyediakan fasilitas pelaporan untuk masyarakat jika menemukan konten yang melanggar aturan. Untuk mempercepat pemblokiran atas laporan konten yang memiliki indikasi eksploitasi seksual anak, KPAI dapat langsung berkoordinasi ke divisi content and safety Facebook.

Dari sisi KPAI sebagai solusi kasus pedofila anak melalui grup Facebook, menyampaikan bahwa pentingnya pengawasan dan pengawalan regulasi yang dibuat secara internal oleh Facebook, dengan membentuk tim siber internal untuk mengontrol dan melakukan patroli siber sehingga konten-konten negatif dapat dicegah sedari awal.

Penanganan Facebook dalam menyetujui dan menindaklanjuti masalah konten negatif dilakukan secara proaktif, tidak sekedar menunggu laporan. Hal ini sebagai wujud tanggung jawab perusahaan dalam menjamin keamanan dan kepatuhan user Facebook.

Framing ketiga dari Republika Online pada tanggal 17 Maret 2017 yang berjudul Pemuda Muhammadiyah: Usut Tuntas
Jaringan Pedofil Internasional ditulis oleh Heri Ruslan.

Berita ini menyampaikan bahwa Pimpinan Pusat Pemuda (PP) Muhammadiyah mengapresiasi upaya Polda Metro Jaya yang berhasil membongkar jaringan pedofil internasional melalui media sosial, Facebook grup. Grup jaringan pedofil internasional yang dibongkar polisi itu memiliki 7.469 anggota. Belum diketahui jumlah anak Indonesia yang menjadi korban para pemangsa anak-anak itu.

Ketua PP Pemuda Muhammadiyah, Jasra Putra dalam pernyataan sikapnya, mengutuk dan mengecam keras kebiadaban pelaku predator anak yang sudah merusak dan mencabik masa depan anak-anak.

Sebagai solusi yang diberikan oleh Pemuda Muhammadiyah, Pemuda Muhammadiyah meminta kepada penegak hukum untuk mengusut tuntas jaringan online kejahatan seksual anak dan melakukan penegakan hukum maksimal terhadap pelaku dewasa.

Selain itu juga Pemuda Muhammadiyah juga mendesak pemerintah, kementerian, dan lembaga terkait untuk melakukan langkahlangkah nyata dalam penanganan anak korban pedofil yang diduga jumlahnya mencapai ribuan. Perlu dilakukan rehabilitasi dan upaya pencegahan agar tidak muncul korban baru.

Secara khusus, Pemuda Muhammadiyah meminta Presiden Joko Widodo untuk mengambil langkah-langkah penyelamatan dan perlindungan atas darurat kejahatan seksual yang akan mengancam 84.000.000 anak Indonesia secara efektif, karena saat ini hampir 70 persen generasi muda di Indonesia aktif dalam dunia maya.

\section{Perbedaan Frame Kompas.com dan Republika Online dalam Kasus Grup Pedofil Di Facebook}

Ketika korporasi media sudah berbicara arah kebijakan redaksi media seringkali harus patuh pada kepentingan pemilik media, sehingga terdapat kepentingan antara pemilik media dan keharusan redaksi dalam menjaga netralitas dan independensi media. Akibatnya, berita menjadi sasaran utama dalam proses konstruksi realitas. Melalui berbagai strategi dan proses yang panjang, sebuah peristiwa 
yang sama bisa saja dikemas secara berbeda oleh media yang berbeda pula.

Berita-berita yang dimunculkan oleh Kompas.com dan Republika Online tentu tidak luput dari konstruksi yang dilakukan oleh kedua belah pihak.

Seperti yang telah dipaparkan sebelumnya, menurut Berger dan juga Luckman, media melalui tiga proses dalam melakukan konstruksi yaitu objektivasi, internalisasi, dan eksternalisasi. Proses tersebut meliputi konstruksi yang dilakukan oleh wartawan terhadap sesuatu sesuai dengan pandangannya.

Media mempunyai strategi wacana tersendiri dalam memaknai peristiwa tersebut. Frame menentukan bagaimana fakta diambil, dilakukan, bagaimana hasil wawancara diperlakukan, bagaimana ditulis dan ditempatkan dalam berita di website. Kompas.com dalam melakukan analisis framing lebih menampilkan berita dengan realitas yang ada sesuai dengan faktanya.

Baik Republika Online maupun Kompas.com, keduanya memang memperlihatkan keberpihakannya pada satu pihak tertentu. Namun, dalam hal ini, Kompas.com terlihat lebih berusaha membuat pemberitaannya menjadi lebih berimbang, yaitu dengan memberi kesempatan kepada berbagai pihak yang terkait untuk memberikan pernyataan.

Republika Online juga selalu mengedepankan fakta hukum, namun Republika Online tidak bermain dengan pernyataan-pernyataan yang disampaikan oleh pengamat yang hanya mengedepankan unsur spekulasi dan prediksi. Pemberitaan kasus pedofilia yang disampaikan di dalam Republika Online tergolong dalam kategori hard news. Isu-isu yang berkembang selalu disampaikan tepat pada keesokan harinya.

Kompas.com dalam memilih narasumber lebih kepada tokoh pejabat pemerintah seperti Pemprov DKI yang mendukung upaya Polda membasmi jaringan pedofil di Facebook. Sedangkan Republika Online lebih memilih tokoh Islam yaitu Pemuda Muhammadiyah yang mengapresiasi upaya Polda Metro Jaya yang berhasil membongkar jaringan pedofil internasional melalui media sosial, Facebook grup.

Pemilihan judul, narasumber, serta penonjolan isu yang berbeda dari keduanya juga akan membuat perbedaan persepsi dari masing-masing pembacanya. Pada prinsipnya, Kompas.com dan Republika Online memiliki latar belakang ideologi yang berbeda. Kompas.com dengan ideologi humanismenya selalu mengedepankan prinsip-prinsip kemanusiaan.

Sedangkan Republika Online sebagai media bernafaskan Islam dengan komunitas muslim terbesar, selalu mengedepankan nilainilai Islam dan nasionalisme dalam setiap pemberitaanya.

\section{PENUTUP}

\section{Simpulan}

Kasus kekerasan seksual terhadap anak selaras dengan meningkatnya kasus pornografi terutama melalui internet dan media sosial. Tindak kekerasan seksual terhadap anak oleh komunitas pedofil yang tergabung dalam grup Facebook "Official Candy's Groups sudah saling berbagi konten pelecehan dan pencabulan terhadap anak-anak.

Ada perbedaan dalam membingkai berita antara Kompas.com dan Republika Online. Perbedaan tersebut terlihat dari pemilihan narasumber. Republika Online sebagai media bernafaskan Islam selalu memilih narasumber yang memiliki pemikiran Islam. Sementara Kompas.com sebagai media nasional dengan ideologi humanisme lebih memilih tokoh pejabat pemerintah sebagai sumber berita dan terlihat lebih umum dalam membingkai pemberitaan.

\section{Saran}

Dalam menghadapi jaringan pedofil yang semakin marak di media sosial, berbagai pihak seperti penegak hukum, pemerintah, kementerian, dan lembaga terkait sebaiknya berupaya tanggap dan cepat untuk melakukan langkah-langkah nyata dalam penanganan anak korban pedofil.

Pemerintah perlu membangun sistem proteksi yang kuat, agar masalah pornografi, 
kejahatan pedofil, dan kejahatan seksual tidak menghantui anak-anak. Bahkan, aparat penegak hukum perlu melakukan tindakan tegas kepada korporasi yang langsung maupun tidak langsung menfasilitasi penyebaran pornografi, kejahatan pedofil, dan kejahatan siber lainnya. Selain itu orang tua dan masyarakat juga dihimbau untuk selalu waspada dalam melindungi, mendampingi, dan memberikan pendidikan bagi anak-anak dalam mengakses internet.

Terkait media sebagai alat penyampaian pesan haruslah selalu menjaga objektivitas dalam menyampaikan pemberitaan dengan menampilkan berita sesuai dengan faktanya. masyarakat agar lebih jeli dalam memaknai setiap informasi yang terkandung di dalam sebuah berita. Karena bisa saja informasi tersebut merupakan hasil konstruksi dari wartawan dan tidak sesuai dengan realitas yang sebenarnya. Pengaruh yang diterima media kadang membuat pergeseran makna yang mestinya disadari dengan baik oleh masyarakat.

\section{DAFTAR PUSTAKA}

American Psychiatric Association (2013) Diagnostic and Statistical Manual of Mental Disorders (DSM-5®). 5th edition. Arlington, American Psychiatric Publishing.

Bungin, B. (2008) Konstruksi Sosial Media Massa. Jakarta, Kencana Prenada Media Group.

Eriyanto (2002) Analisis Framing: Konstruksi, Ideologi, dan Politik Media. Yogyakarta, LkiS.

Foust, J.C. (2005) Online Journalism: Principles and Practices of News for the Web. Scottsdale, AZ, Holcomb Hathaway Publishers.

Gerbner, G. (2007) Cultivation Analysis in West and Turner: Introducing Communication Theory. New York, McGraw Hill.

Kompas (2017a) About Us. [Online]. 2017. Available from: http://inside.kompas.com/ [Accessed: 17 March 2017].

Kompas (2017b) Artikel-artikel Kompas.com. [Online]. 2017. Kompas.com. Available from: $\quad$ http://nasional.kompas.com [Accessed: 17 March 2017].

Kompas (2017c) Mengapa Seseorang Bisa Menjadi Pedofil? [Online]. 2017. Available from:

http://sains.kompas.com/read/2017/03/17/16

1500123/mengapa.seseorang.bisa.menjadi.p edofil.?page $=$ all [Accessed: 25 April 2017].

Lanning, K. V. (2010) Child Molesters: A Behavioral Analysis For Professionals Investigating the Sexual Exploitation of Children. [Online] Available from: https://www.icmec.org/wpcontent/uploads/2015/10/US-NCMECChild-Molesters-A-Behavioral-AnalysisLanning-2010.pdf.

Mawardi, G. (2012) Pembingkaian Berita Media Online (Analisis Framing Berita Mundurnya Surya Paloh dari Partai Golkar di mediaindonesia. com dan vivanews. com Tanggal 7 September 2011). Universitas Indonesia.

Nailufar, N.N. (2017) Cerita 'Emak-emak' Ungkap Grup Pedofil di Facebook. [Online]. 2017. Kompas.com. Available from: http://megapolitan.kompas.com/read/2017/0 3/17/10034041/cerita.emak-

emak.ungkap.grup.pedofil.di.facebook?utm_ source=GoogleNews\&utm_medium=EPick \&utm_campaign=partner\&google_editors_p icks=true [Accessed: 24 April 2017].

Ogloff, J.R., Cutajar, M.C., Mann, E., Mullen, P., et al. (2011) Child Sexual Abuse and Subsequent Offending and Victimisation: A 45-year Follow-up Study. Trends and Issues in Crime and Criminal Justice. [Online] (440), 1. Available from: https://search.informit.com.au/documentSu mmary; $\mathrm{dn}=578804228398477$;res=IELHSS.

Republika (2017) Artikel-artikel Republika Online. [Online]. 2017. Republika. Available from: www.republika.co.id [Accessed: 17 March 2017].

Romli, A.S.M. \& Syamsul, A. (2012) Jurnalistik Online: Panduan Praktis Mengelola Media Online. Bandung, Nuansa Cendekia.

Setiawan, A. (2017) Penanganan Masalah Pornografi Anak Rendah, Setahun Hanya 1 Kasus. [Online]. 2017. Tempo. Available from:

https://nasional.tempo.co/read/news/2017/03 /20/063857601/penanganan-masalahpornografi-anak-rendah-setahun-hanya-1kasus [Accessed: 1 January 2017].

Sobur, A. (2001) Analisis Teks Media. Bandung, PT. Remaja Rosdakarya.

Sumadiria, A.S.H. (2005) Jurnalistik Indonesia: Menulis Berita dan Feature: Panduan Praktis Jurnalis Professional. Simbiosa Rekatama Media. 
Suryawati, I. (2011) Jurnalistik Suatu Pengantar. Bogor, Ghalia Indonesia.

Tempo (2017) Majalah Tempo, 27 March - 2 April. Vandra, R. (2015) Pemaknaan Ibu tehadap Kasus Pedofilia. Universitas Indonesia.

VoA Indonesia (2017) Komnas Anak: Kekerasan Seksual terhadap Anak Sudah Darurat. [Online]. 2017. Available from: http://www.voaindonesia.com/a/kpaikekerasan-seksual-terhadap-anak-sudahdarurat/1902840.html [Accessed: 1 January 2017]. 